\title{
EMPATI DAN PEMAAFAN PADA MAHASISWA FAKULTAS PSIKOLOGI UIN SUSKA RIAU
}

\author{
Dwi Indra Lestari / Ivan Muhammad Agung
}

Fakultas Psikologi UIN Sultan Syarif Kasim Riau

Diterima tanggal 10 Oktober 2016 / Disetujui tanggal 27 Oktober 2016

\begin{abstract}
Forgiveness has one important in human interpersonal relation. The purpose of this study was to examine the relationship between empathy and forgiveness on undergraduate student. The participants undergraduate student were 309 (47: men, 262, women) from faculty of Psychology UIN Suska Riau. This research used two kinds of scale, empathy and forgiveness scale. The result showed: there is a significant and positive correlation between empatby and forgiveness. The Implication of this result are discussed on the interpersonal relation contexts.
\end{abstract}

Kata kunci: empathy, forgiveness, interpersonal relation

\section{Pendahuluan}

Sebagian besar dari individu pernah terluka dan memerlukan cara untuk mengatasi luka tersebut. Cara untuk mengatasi luka salah satunya adalah dengan memaafkan. Memaafkan adalah salah satu cara untuk melepaskan emosi-emosi negatif yang muncul akibat perlakuan menyakitkan yang dilakukan seseorang. Semakin besar luka maka akan semakin sulit untuk memaafkan dan semakin parah rasa sakit hati semakin lama pula waktu yang diperlukan untuk memaafkan. Memaafkan menggantikan rasa sakit dengan rasa damai (Post dan Neimark, 2007).

Salah satu argumen yang paling sering dikemukakan dan paling salah terhadap memaafkan adalah jika memaafkan berarti menunjukkan bahwa orang yang melakukan kesalahan tersebut bisa berlaku sesuka hati (Charlot Witvliet, dalam Post dan Neimark, 2007). Tetapi memaafkan bukanlah tentang memberikan kekuasaan. Jika dapat memaafkan dengan sangat baik, individu harus menggali lebih dalam dan hal ini membutuhkan keberanian serta empati.

Memaafkan bukanlah tindakan yang mudah. Memaafkan membutuhkan sebuah perjuangan dan proses. McCullough dkk. (1997) menyatakan bahwa memaafkan merupakan upaya untuk membawa perasaan negatif dan menggantinya dengan pikiran, perasaan, dan tindakan positif. Pada kenyataannya, memaafkan tidak mudah dilakukan apalagi secara cepat. Selalu ada persoalan psikologis di antara dua pihak yang pernah mengalami keretakan hubungan akibat suatu kesalahan. Permintaan maaf memiliki kemampuan untuk menghapuskan kebencian dan kepahitan (Post dan Neimark, 2007), dalam hal ini yaitu kebencian dan kepahitan yang dirasakan bagi orang yang tersakiti. Memaafkan efektif mengembalikan hubungan sosial yang rusak antara individu tersebut dengan orang yang menyakitinya (McCullough dkk., 2006).

Beberapa peneliti merasa bahwa semakin penuh suatu permintaan maaf-mengakui tanggung jawab atas sebuah kesalahan, mengungkapkan penyesalan, dan menawarkan untuk memperbaiki keadaan-semakin besar pula kekuatannya (Post dan Neimark, 2007). Beberapa penelitian (Darby dan Schlenker, 1982; Ohbuchi, 1989) menemukan bahwa meminta maaf sangat efektif dalam mengatasi konflik interpersonal, karena 
permintaan maaf merupakan sebuah penyataan tanggung jawab tidak bersyarat atas kesalahan dan sebuah komitmen untuk memperbaikinya. Pemaafan berkaitan dengan peningkatan kebahagiaan, keramahan, harapan dan kemampuan untuk membangun kembali kedekatan dalam hubungan (Lyubomirsky, 2007; Neto dan Mullet, 2004).

Ada banyak hal yang mempengaruhi seseorang dalam proses pemaafan, salah satunya adalah empati. Seperti yang dikatakan McCullough (2000) dan Worthington (1998) dalam tulisannya, bahwa empati merupakan penentu kemampuan untuk memaafkan. Enright, Freedman, dan Rique (1998) menyatakan bahwa empati adalah faktor dalam fase kerja dari proses pemaafan. Empati adalah kemampuan seseorang untuk mengerti tentang perasaan dan emosi orang lain serta kemampuan untuk membayangkan diri sendiri ditempat orang lain (Hurlock, 1999).

Empati termasuk kemampuan untuk merasakan keadaan emosional orang lain, merasa simpatik dan mencoba menyelesaikan, dan mengambil perspektif orang lain (Baron \& Byrne, 2005). Melalui kemampuan untuk merasakan kondisi emosional orang lain, maka individu bisa membina hubungan yang baik dengan orang lain. Empati meliputi komponen afektif maupun kognitif (Baron \& Byrne, 2005). Secara afektif, orang yang berempati merasakan apa yang orang lain rasakan. Secara kognitif, orang yang berempati memahami apa yang orang lain rasakan dan mengapa. Walaupun empati dianggap sebagai keadaan emosional, sering kali empati memiliki komponen kognitif atau kemampuan melihat keadaan psikologis dalam diri orang lain, atau apa yang disebut dengan mengambil perspektif orang lain. Ketika individu akan memberikan maaf, individu tersebut pasti mengingat kembali rasa sakit yang diterima dari orang yang menyakiti dan membutuhkan empati yang baik (McCullough, 2000). Perasaan positif seperti empati akan memberikan kontribusi pada perkembangan moral orang lain khususnya remaja. Ketika individu memaafkan seseorang yang telah melukainya terjadi penurunan motivasi untuk menghindari dan menyakiti orang tersebut (Mc Cullough, 2000).

Berdasarkan hasil penelitian sebelumnya yang telah dilakukan oleh Sulistyorini Tri Hapsari pada tahun 2011 di Semarang tentang "Hubungan antara Empati dengan Pemaafan Remaja dengan Orangtua Bercerai pada Suku Jawa" mendapatkan hasil setelah dilakukan uji hipotesis yaitu menunjukkan nilai koefisien korelasi sebesar rxy $=0,371$ dengan $\mathrm{p}<0,05$. Artinya penelitian tersebut menunjukkan bahwa ada hubungan positif yang signifikan antara empati dengan pemaafan. Hasil yang sama juga terdapat dalam penelitian yang telah dilakukan oleh Ni Made Taganing Kurniati yang berjudul "Memaafkan: Kaitannya Dengan Empati dan Pengelolaan Emosi”. Dari penelitian tersebut Sebanyak 31 studi dari 7 penelitian $(\mathrm{N}=4.544)$ digunakan untuk menganalisis hubungan antara empati dengan memaafkan. Hasilnya menunjukkan bahwa terdapat hubungan positif signifikan antara empati dan memaafkan. Dengan demikian, semakin tinggi empati maka semakin tinggi pula pemaafannya.

Hasil penelitian diatas didukung oleh pernyataan McCullough (2000) yang mengatakan bahwa empati akan mempengaruhi atau memotivasi seseorang untuk memberikan maaf terhadap orang lain. Artinya, semakin baik seseorang memiliki rasa untuk berempati, maka akan semakin baik pula dalam memberikan pemaafan terhadap orang yang menyakitinya. Jika ia mampu menempatkan diri pada sudut pandang pihak yang menyakiti, maka ia akan dapat memahami motivasi dan alasan kenapa orang yang menyakiti melakukan 
hal tersebut. McCullough, Rachal, Worthingthon (1997) juga menyatakan bahwa empati merupakan elemen yang sangat penting dalam pemaafan karena melalui empati, individu mampu memaafkan dan menumbuhkan perasaan positif terhadap orang yang menyakitinya. Berdasarkan pernyataan tersebut, maka dapat disimpulkan bahwa empati memang merupakan aspek yang penting dalam pemberian maaf.

Kemampuan untuk empati mulai dapat dimiliki seseorang ketika menduduki masa akhir kanak-kanak awal (Hurlock, 1999). Dengan demikian dapat dikatakan bahwa semua individu memiliki dasar kemampuan untuk berempati, hanya saja berbeda tingkat kedalaman dan mengaktualisasikannya. Hal ini berarti pada masa dewasa awal individu juga sudah memiliki kemampuan empati.Menurut Santrok (1999), dewasa awal termasuk masa transisi, baik transisi secara fisik, transisi secara intelektual maupun transisi peran sosial. Masa dewasa awal adalah masa beralihnya pandangan egosentris menjadi sikap yang empati. Pada masa dewasa awal ini individu sudah menciptakan dan menjalin hubungan interpersonal dengan orang di sekelilingnya.

Dalam berinteraksi dengan orang lain seseorang kadang-kadang berbuat salah kepada orang lain. Begitu juga yang terjadi pada mahasiswa. Mahasiswa dalam menjalin hubungan dengan orang lain baik dengan teman sebayanya ataupun dengan orang yang berada disekitarnya tidak menutup kemungkinan akan terjadi konflik. Mahasiswa tentu pernah mengalami perlakuan dan situasi yang mengecewakan atau menyakitkan. Hal inilah yang membuat hubungan mahasiswa dengan orang disekililingnya menjadi bermasalah, sehingga membutuhkan sikap untuk memaafkan.Ketika seseorang tidak bisa untuk memaafkan, ia akan memperoleh berbagai kerugian diantaranya yaitu hati dipenuhi emosi negatif seperti dendam, marah dan benci terhadap orang yang telah menyakitinya. Rasa marah, benci dan dendam juga berpengaruh terhadap psikologis. Ahliahli psikologi sosial menjelaskan bahwa perilaku agresif terjadi akibat rasa benci dan rasa dendam yang dimiliki seseorang (Nashori, 2008). Selain itu, tidak memaafkan berkorelasi positif dengan depresi, kecemasan, permusuhan dan neurotisisme ( Lyubomirsky, 2007). Berdasarkan latar belakang yang telah dijelaskan diatas, peneliti merasa tertarik untuk meneliti "Hubungan Antara Empati dengan Pemaafan pada Mahasiswa Fakultas Psikologi UIN Suska Riau"

\section{Metode Populasi dan Sampel}

Populasi didefinisikan sebagai keseluruhan subjek penelitian (Arikunto, 2010). Populasi dalam penelitian ini adalah mahasiswa aktif fakultas Psikologi UIN Suska Riau Tahun Akademik 2013-2014 yang berjumlah 1.127 dengan rincian sebagai berikut: 


\section{Tabel 1}

Data Mahasiswa Aktif Semester Ganjil

Tahun Akademik 2013-2014

\begin{tabular}{ccc}
\hline No & Angkatan & Jumlah \\
\hline 1. & 2013 & 394 \\
2. & 2012 & 229 \\
3. & 2011 & 179 \\
4. & 2010 & 181 \\
5. & 2009 & 144 \\
\hline & Jumlah & 1.127 \\
\hline
\end{tabular}

Sumber: Data bagian akademik, Oktober 2013.

Sampel adalah sebagian atau wakil populasi yang diteliti (Arikunto, 2010). Teknik yang digunakan dalam pengambilan sampel pada penelitian ini adalah dengan menggunakan cluster random sampling. Cluster random sampling adalah pengambilan sampel dengan cara melakukan randomisasi terhadap kelompok, bukan terhadap subjek secara individual. Kelompok yang dimaksud disini adalah kelas. Jadi, peneliti mengambil beberapa kelas yang akan dijadikan sampel secara acak berdasarkan jumlah seluruh kelas dari angkatan tahun 2009 sampai tahun 2013 dengan cara undian. Sebelumnya peneliti membuat daftar jumlah seluruh kelas dari angkatan 2009 sampai 2013, kemudian memberi kode pada setiap kelas dan menuliskannya pada selembar kertas kecil lalu digulung. Kertas yang sudah digulung kemudian dimasukkan kedalam tempolong dan tempolong dikocok. Peneliti mengambil 9 kelas yang dijadikan sampel penelitian sehingga didapatkan sampel sebanyak 309 orang.

\section{Pengukuran}

Pengukuran dalam penelitian ini menggunakan dua alat ukur dengan jenis skala model Likert, yaitu pemaafan dan empati.

1. Skala Pemaafan.

Variabel pemaafan dalam penelitian ini diukur dengan menggunakan Transgression-Related Interpersonal Motivations (TRIM-18). Transgression-Related Interpersonal Motivations (TRIM-18) adalah skala yang dikembangkan oleh Michael E. McCullough. Peneliti juga menambahkan beberapa item yang mempunyai maksud sama untuk mengukur pemaafan sehingga berjumlah 30 item. Menurut McCullough (2000), aspek pemaafan terdiri dari tiga unsur, yaitu: avoidance motivations, yaitu motivasi penghindaran terhadap orang yang telah menyakiti, revenge motivations, yaitu motivasi untuk membalas dendam, dan benevolence motivations, yaitu motivasi melakukan kebaikan dan berdamai dengan pelaku. Rentang penilaian, 1= sangat tidak sesuai sampai $5=$ sangat sesuai, contoh item "Saya tetap ingin menjaga hubungan baik dengan orang yang telah menyakiti saya." Setelah dilakukan try out, 3 item yang gugur dengan reliabilitas 0,918. 
2. Skala Empati

Variabel empati dalam penelitian ini diukur dengan Interpersonal Reactivity Index (IRI) dari Davis. Peneliti juga menambahkan beberapa item yang mempunyai maksud sama untuk mengukur empati sehingga berjumlah 36 item. Skala Interpersonal Reactivity Index (IRI) terbagi dalam empat subskala. Keempat subskala tersebut yaitu Perspektive-Taking (PT) terdiri atas item-item yang mengukur kecenderungan untuk memahami pandangan-pandangan orang lain, Emphatic Concern (EC) untuk mengukur kecenderungan terhadap pengalaman-pengalaman yang berhubungan dengan "kehangatan", "rasa iba", dan perhatian terhadap kemalangan oranglain, Personal Distress (PD) mengukur kecemasan pribadi yang berorientasi pada diri sendiri serta kegelisahan dalam mengahadapi setting interpersonal yang tidak menyenangkan dan Fantasy (FS) cenderung untuk menempatkan diri sendiri ke dalam perasaan dan perilaku-perilaku dari karakter-karakter yang ada di dalam buku cerita, novel, film, dan lain sebagainya. Rentang penilaian, $1=$ sangat tidak sesuai sampai $5=$ sangat sesuai. Contoh "Saya merasakan sedih ketika melihat orang lain terluka." Setelah dilakukan try out, 10 item yang gugur dengan reliabilitas 0,932.

\section{Uji Normalitas dan Linearitas}

Berdasarkan uji normalitas diperoleh rasio skewness untuk variabel empati (X) sebesar -4,230 dan rasio kurtosis sebesar 5,97. Sedangkan untuk variabel pemaafan (Y) diperoleh rasio skewness sebesar -2,546 dan rasio kurtosis sebesar -0,090. Maka dapat disimpulkan bahwa sebaran pada variabel empati tidak normal sedangkan variabel pemaafan normal. Berdasarkan hasil uji linearitas yang telah dilakukan diperoleh $\mathrm{F}$ sebesar 32.902 dengan taraf signifikansi 0,000, sehingga dapat disimpulkan bahwa kedua variabel linear. Hasil uji linear dalam penelitian ini diketahui bahwa arah hubungan kedua variable positif.

\section{Uji Hipotesis}

Untuk menguji hipotesis yang diajukan diterima atau ditolak, maka dilakukan analisis data. Oleh karena asumsi normalitas tidak terpenuhi, maka teknik statistik yang digunakan adalah teknik nonparametrik, yaitu korelasi Rank Spearman dengan bantuan program komputerisasi SPSS 16.0 for windows. Berdasarkan hasil analisis teknik korelasi Rank. Spearman diperoleh koefisien antara empati dengan pemaafan sebesar 0,316 pada taraf signifikansi 0,000 (Lampiran J). Hipotesis dikatakan signifikan jika memiliki taraf signifikan kurang dari $1 \%(\mathrm{p}<0,01)$ atau kurang dari 5\% $(\mathrm{p}<0,05)$. Dengan demikian dapat dikatakan bahwa antara empati dengan pemaafan terdapat hubungan yang signifikan. Jadi hipotesis yang diajukan dalam penelitian ini diterima, yaitu terdapat hubungan positif antara empati dengan pemaafan pada mahasiswa

\section{Analisis Tambahan}

Untuk melihat korelasi tiap aspek dari empati dengan pemaafan, dilakukan uji korelasi pada setiap aspek empati yaitu perspective taking, fantasy, emphatic concern dan personal distress dengan pemaafan. Berdasarkan uji korelasi pada tiap aspek tersebut, didapatkan hasil korelasi sebagai berikut: 
Tabel 2

Korelasi Tiap Aspek Empati Dengan Pemaafan

\begin{tabular}{|c|c|c|c|}
\hline Aspek Empati & Rxy & $\mathbf{P}$ & Keterangan \\
\hline Perspective taking & $0,393^{* *}$ & 0,000 & $\begin{array}{l}\text { Sangat } \\
\text { signifikan }\end{array}$ \\
\hline Fantasy & 0,046 & 0,419 & $\begin{array}{l}\text { Tidak } \\
\text { signifikan }\end{array}$ \\
\hline Emphatic concern & $0,439^{* *}$ & 0,000 & $\begin{array}{l}\text { Sangat } \\
\text { signifikan }\end{array}$ \\
\hline Personal ditress & $0,204^{* *}$ & 0,000 & $\begin{array}{l}\text { Sangat } \\
\text { signifikan }\end{array}$ \\
\hline
\end{tabular}

**. Correlation is significant at the 0.01 level (2-tailed).

Berdasarkan tabel 2 menunjukkan hasil bahwa hubungan antara aspek perspective taking dengan pemaafan sebesar 0,393 dengan taraf signifikansi 0,000 (sangat signifikan). Hubungan antara aspek fantasy dengan pemaafan sebesar 0,046 dengan taraf signifikansi 0,419 (tidak signifikan). Hubungan antara aspek emphatic concern dengan pemaafan sebesar 0,439 dengan taraf signifikansi 0,000 (sangat signifikan).

Hubungan antara aspek personal distress dengan pemaafan sebesar 0, 204 dengan taraf signifikansi 0,000 (sangat signifikan). Hal ini berarti aspek perspective taking, emphatic concern dan personal distress memilikihubungan yang sangat signifikan dengan pemaafan.

\section{Korelasi Empati dengan Pemaafan Berdasarkan Jenis Kelamin}

Untuk melihat korelasi antara empati dengan pemaafan berdasarkan jenis kelamin, dilakukan uji korelasi secara terpisah antara jenis kelamin laki-laki dengan jenis kelamin perempuan. Secara rinci dapat dilihat pada tabel berikut:

\section{Tabel 3}

Korelasi Empati Dengan Pemaafan Berdasarkan Jenis Kelamin

\begin{tabular}{|c|c|c|c|}
\hline Jenis Kelamin & $\mathbf{N}$ & $\mathbf{R x y}$ & $\mathbf{P}$ \\
\hline Laki-laki & 47 & 0,262 & 0,075 \\
\hline Perempuan & 262 & $0,304^{* *}$ & 0,000 \\
\hline
\end{tabular}

**. Correlation is significant at the 0.01 level (2-tailed).

Berdasarkan tabel 3 diketahui hubungan antara empati dengan pemaafan pada jenis kelamin perempuan sebesar rxy 0,304 dengan signifikansi 0,000 (sangat signifikan), sedangkan hubungan antara empati dengan pemaafan pada jenis kelamin laki-laki sebesar rxy 0,262 dengan signifikansi 0,075 (tidak signifikan). Sehingga dapat dikatakan bahwa terdapat hubungan yang sangat signifikan antara empati dengan pemaafan 
pada mahasiswa perempuan Fakultas Psikologi UIN SUSKA Riau dan tidak ada hubungan yang signifikan antara empati dengan pemaafan pada mahasiswa laki- laki Fakultas Psikologi UIN suska Riau

\section{Pembahasan}

Hasil penelitian menunjukkan bahwa hipotesis diterima, yaitu terdapat hubungan positif antara empati dengan pemaafan pada mahasiswa Fakultas Psikologi UIN Suska Riau. Uji hipotesis dengan menggunakan teknik korelasi Rank Spearman dengan bantuan spss 16.0 for windows diperoleh koefisien korelasi sebesar 0,316 dengan taraf signifikansi 0,000. Dengan demikian dapat dikatakan bahwa antara empati dengan pemaafan terdapat hubungan yang positif. Artinya semakin tinggi empati mahasiswa maka semakin tinggi pula pemaafannya. Begitu juga sebaliknya, semakin rendah empati mahasiswa maka semakin rendah juga pemaafannya.

Hasil yang sama juga terdapat pada penelitian yang telah dilakukan oleh Hapsari (2011) mendapatkan hasil bahwa ada hubungan positif antara empati dengan pemaafan. Hasil penelitian ini juga didukung oleh pernyataan Enright, Freedman, Rique (1998) menyatakan bahwa empati sebagai faktor dalam fase kerja dari proses pemaafan. Hal yang senada juga disampaikan oleh McCullough (2000) yang mengatakan bahwa empati akan mempengaruhi atau memotivasi seseorang untuk memberikan maaf terhadap orang lain. Artinya, semakin baik seseorang memiliki rasa untuk berempati, maka akan semakin baik pula dalam memberikan pemaafan terhadap orang yang menyakitinya. Jika mahasiswa mampu menempatkan diri pada sudut pandang orang yang telah menyakiti, maka mahasiswa akan mampu memahami motivasi dan alasan kenapa orang yang telah menyakiti melakukan hal tersebut. Menurut Luskin (dikutip Wirawan, 2010) ciri-ciri yang dimiliki oleh orang yang mudah memaafkan adalah orang yang punya penjelasan rasional terhadap sikap orang lain yang telah membuat mereka tersinggung. Melalui pemahaman ini, maka ia akan lebih mudah memberikan maaf terhadap orang yang telah menyakiti.

Hasil penelitian ini diperkuat oleh McCullough dkk (1997) yang menyatakan bahwa empati merupakan elemen yang sangat penting dalam pemaafan karena melalui empati, individu mampu memaafkan dan menumbuhkan perasaan positif terhadap orang yang telah menyakiti. Berdasarkan pernyataan tersebut, maka dapat disimpulkan bahwa empati memang merupakan aspek yang penting dalam pemberian maaf. Berdasarkan hasil uji korelasi hubungan antara empati dengan pemaafan secara terpisah antara jenis kelamin laki-laki dengan perempuan, diketahui bahwa terdapat hubungan yang signifikan antara empati dengan pemaafan pada mahasiswa perempuan (nilai r 0,304 dengan taraf signifikansi 0,000).Akan tetapi berbeda halnya dengan mahasiswa laki-laki. Berdasarkan hasil analisis data ditemukan bahwa tidak ada hubungan yang signifikan antara empati dengan pemaafan pada mahasiswa laki-laki (nilai $\mathrm{r}$ sebesar 0,262 dengan taraf signifikansi 0,075).

Hal ini juga dapat dibuktikan melalui perbedaan empati dan pemaafan dari laki-laki dan perempuan. Berdasarkan hasil dalam penelitian ini, empati perempuan lebih tinggi dibandingkan dengan empati pada lakilaki dan pemaafan pun lebih tinggi pada perempuan dibandingkan pada laki-laki. Hasil temuan dalam penelitian ini diperkuat oleh pernyataan Baron \& Byrne (2005) bahwa wanita mengekspresikan tingkat empati 
yang lebih tinggi daripada pria, hal ini disebabkan baik oleh perbedaan genetis atau perbedaan pengalaman sosialisasi. Wanita lebih cenderung menyadari emosinya daripada pria, lebih berbagi penghargaan dan ingin mempertahankan hubungan interpersonal dengan orang lain (Baron \& Byrne, 2004). Berikutnya, pada penelitian ini menunjukkan bahwa pemaafan perempuan lebih tinggi dibandingkan pada laki-laki. Penelitian ini menunjukkan hasil yang sama dengan penelitian yang dilakukan oleh Daniel (2010). Berdasarkan hasil penelitian tersebut, pria dengan wanita memiliki perbedaan yang signifikan dalam pemaafan. Wanita memiliki pemaafan yang lebih tinggi dibandingkan pria. Hal ini dikarenakan menurut Brizendine (2010) bahwa pria sering menikmati konflik antar pribadi dan persaingan, sedangkan pada wanita konflik lebih mungkin memicu serangkain negatif hormon yang menimbulkan stress serta rasa gelisah dan takut.

Berdasarkan hasil uji korelasi setiap aspek empati dengan pemaafan diketahui bahwa aspek perspective taking, emphatic concern dan personal distress mempunyai hubungan yang sangat signifikan dengan pemaafan. Hal ini dikarenakan ketika individu akan memberikan maaf, individu tersebut pasti mengingat kembali rasa sakit yang diterima dari orang yang menyakiti. Hal ini melibatkan perspective taking. Perspective taking berkaitan dengan theory of mind. Menurut theory of mind kunci pokok dari perspective taking terletak pada kemampuan seseorang dalam mengoptimalkan pikirannya untuk memahami kondisi orang lain, melalui pemaknaan sikap dan perilaku yang dilihatnya (Taufik, 2012). Melalui kemampuan pemahaman dan pengambilan sudut pandang (perspective taking) dari orang yang menyakiti, individu bisa menempatkan dirinya pada orang yang telah menyakitinya dan mengetahui motivasi apa yang bisa menyebabkan pelaku melakukan hal tersebut hingga akhirnya individu memutuskan untuk dapat memaafkan.

Emphatic concern termasuk dalam komponen afektif dalam empati (Taufik, 2012). Secara afektif, orang yang berempati merasakan apa yang orang lain rasakan. Empati secara afektif merujuk pada kemampuan menselaraskan pengalaman emosional pada orang lain, yang terdiri atas simpati, sensitivitas, dan sharing penderitaan yang dialami orang lain seperti perasaan dekat terhadap kesulitan-kesulitan orang lain yang diimajinasikan seakan-akan dialami oleh diri sendiri (Colley, dalam Taufik 2012). Apabila individu mampu membayangkan jika dirinya sendiri berada disituasi yang pernah melakukan kesalahan terhadap orang lain dan membutuhkan pemaafan maka individu tersebut pasti mampu memaafkan kesalahan orang yang telah menyakitinya. Hal ini dikarenakan individu mampu merasakan apa yang dibutuhkan oleh seorang yang telah melakukan kesalahan, yaitu kebutuhan untuk dimaafkan.

Sama halnya dengan aspek emphatic concern, aspek personal distresss juga termasuk kedalam komponen afektif dalam empati. Personal distresss berarti kecemasan pribadi yang berorientasi pada diri sendiri serta kegelisahan dalam mengahadapi setting interpersonal yang tidak menyenangkan (Davis, 1983). Setting interpersonal yang tidak menyenangkan disini diartikan yaitu ketika mahasiswa mengalami konflik dengan orang lain merasa berada pada situasi yang tidak menyenangkan, cemas dan merasa gelisah. Sehingga hal ini membuat individu yang merasa tersakiti akan memaafkan orang yang telah menyakitinya untuk mendapatkan ketenangan hati. Hal ini telah dibuktikan secara empiris dalam penelitian eksperimen yang dilakukan Frederic Luskin (dalam Taufik, 2012) yang menunjukkan adanya efek memaafkan secara total terhadap kesehatan emosional. Mahasiswa yang dilatih memaafkan ternyata jauh lebih tenang kehidupan sosialnya. Mahasiswa 
menjadi tidak mudah marah, tidak mudah tersinggung dan dapat membina hubungan lebih baik dengan sesama (Nashori, 2008).

\section{Penutup}

Berdasarkan hasil analisis dan pembahasan dalam penelitian ini, dapat ditarik kesimpulan sebagai berikut:

1. Empati berhubungan positif dengan pemaafan pada mahasiswa Fakultas Psikologi UIN Suska Riau. Semakin tinggi empati yang dimiliki oleh mahasiswa Fakultas Psikologi UIN Suska Riau, maka semakin tinggi juga pemaafan yang dimiliki oleh mahasiswa Fakultas Psikologi UIN Suska Riau. Begitu juga sebaliknya.

2. Hubungan empati dengan pemaafan lebih kuat pada perempuan dibandingankan laki-laki.aspek empati yang berhubungan dengan pemaafan adalah perspective taking, emphatic concern dan personal distress sementara fantasi tidak berhubungan signifikan dengan pemaafan.

\section{DAFTAR PUSTAKA}

Arikunto, S (2010). Prosedur Penelitian Suatu Pendekatan Praktik. Yogyakarta: PT. Rineka Cipta.

Baron, R A., Byrne, D. (2004). Psikologi Sosial Jilid 1. Alih Bahasa: Ratna Djuwita. Edisi kesepuluh. Jakarta: Erlangga.

Baron, R A., Byrne, D. (2005). Psikologi Sosial Jilid 2. Alih Bahasa: Ratna Djuwita. Edisi kesepuluh. Jakarta: Erlangga.

Brizendine, L. (2010). Male Brain. Jakarta: PT. Ufuk Publishing Press.

Daniel. (2010). Perbedaan Pemaafan Antara Pria Dengan Wanita Pada Mahasiswa UKRIDA dan UNTAR. Skripsi. (Tidak Diterbitkan). Jakarta: Fakultas Psikologi Universitas Kristen Krida Wacana.

Davis, Mark H. (1980). A Multidimensional Approach to Individual Differences in Empathy. The University of Texas at Austin.

Davis, Mark H. (1983). Measuring Individual Differences in Emphaty: Evidence for a Multidimensional Approach. Journal of Personality and Social Psychology. Vol. 44. No. 1. 113-126.

Hurlock, E.B. (1993). Perkembangan Anak Jilid 2. Terjemahan oleh Thandrasa \& Zarkasih. Jakarta: PT. Erlangga

Hurlock, E.B. (1999). Perkembangan Anak Jilid 1. Alih bahasa oleh Tjandrasa \& Zarkasih. Jakarta: PT. Erlangga Kurniati, Ni Made Taganing. (2009). Memaafkan: Kaitannya Dengan Empati Dan Pengelolaan Emosi. 3, 1885-2559. McCullough, M. E. (2000). Forgiveness As Human Strength: Theory, Measurement, and Links To WellBeing. Journal of Social and Clinical Psychology. 19 (1), 43-55. 
McCullough, M E., Root, Lindsey M., Cohen, Adam D. (2006). Writing About the Benefits of an Interpersonal Transgression Facilitates Forgiveness. Journal of Consulting and Clinical Psychology, 74, 887-897.

McCullough, Michael E., Worthington, Everentt L., Rachal, Kenneth. (1997). Interpersonal Forgiving in Close Relationships. Journal of Personality and Social Psychology. 73 (2), 321-336.

Nashori, F. (2008). Psikologi Sosial Islam. Bandung: PT. Refika Aditama.

Post, S \& , Neimark, J. (2011). Why Good Things Happen to Good People. Bandung: PT. Mizan Pustaka.

Rijavec, Mazda., Jurcec, Lana., Mijocevic, Ivana., Kasica, Os Bartola., Zagreb. (2010). Gender Differences in the Relationship between Forgiveness and Depression/Happiness. Psibologijske teme 19. 1, 189-202.

Sangadji, Mamang Etta., Sofiah. (2010). Metode Penelitian Pendekatan Praktis dalam Penelitian. Yogyakarta.

Santrock, John W.S. (2007). Remaja Jilid 1 Edisi 11. Alih bahasa: Benedictine Widyasinta. Jakarta: Erlangga.

Taufik. (2012). Empati Pendekatan Psikologi Sosial. Jakarta: PT. Raja Grafindo Persada.

Toussaint, Loren., Webb, J R. (2005). Gender Differences in the Relationship Between Empathy and Forgiveness. 145(6): 673-685.

Tri Hapsari, S. (2011). Hubungan antara Empati dengan Pemaafan Remaja dengan Orangtua Bercerai pada Suku Jawa. Skripsi. Perpustakaan Universitas Katolik Sogijapranata Semarang.

Wirawan, P. (2010). Kecenderungan Permaafan Ditinjau dari Kecerdasan Emosional. Skripsi. (Tidak Diterbitkan). Semarang: Fakultas Psikologi Unika Soegijapranata. 